\title{
(Ultra) high pressure homogenization for continuous high pressure sterilization of pumpable foods - a review
}

\author{
Erika Georget ${ }^{1,2}$, Brittany Miller ${ }^{1}$, Michael Callanan ${ }^{3}$, Volker Heinz ${ }^{1}$ and Alexander Mathys ${ }^{1}$ * \\ ' German Institute of Food Technologies (DIL), Quakenbrueck, Germany \\ 2 Institute of Food Chemistry, Leibniz University of Hanover, Hanover, Germany \\ ${ }^{3}$ Nestlé Research Center, Lausanne, Switzerland
}

Edited by:

Lilia Ahrné, SIK - The Swedish

Institute for Food and Biotechnology,

Sweden

\section{Reviewed by:}

Javier Carballo, University of Vigo,

Spain

Joaquina Teresa Dias, Polytechnic

Institute of Bragança, Portugal

\section{*Correspondence:}

Alexander Mathys, German Institute

of Food Technologies (DIL),

Prof.-von-Klitzing-Street 7,

Quakenbrueck 49610, Germany

e-mail: a.mathys@dil-ev.de
Bacterial spores have a strong resistance to both chemical and physical hurdles and create a risk for the food industry, which has been tackled by applying high thermal intensity treatments to sterilize food. These strong thermal treatments lead to a reduction of the organoleptic and nutritional properties of food and alternatives are actively searched for. Innovative hurdles offer an alternative to inactivate bacterial spores. In particular, recent technological developments have enabled a new generation of high pressure homogenizer working at pressures up to $400 \mathrm{MPa}$ and thus, opening new opportunities for high pressure sterilization of foods. In this short review, we summarize the work conducted on (ultra) high pressure homogenization (U)HPH to inactivate endospores in model and food systems. Specific attention is given to process parameters (pressure, inlet, and valve temperatures). This review gathers the current state of the art and underlines the potential of UHPH sterilization of pumpable foods while highlighting the needs for future work.

Keywords: ultra high pressure homogenization, bacterial spore, sterilization, food, continuous processing

\section{INTRODUCTION}

Mechanical homogenization was defined as the capability of producing a homogeneous size distribution of particles suspended in a liquid, by forcing the liquid under the effect of high pressure through a disruption valve (1). The first occurrence of homogenization for the stabilization of food and dairy emulsions is dated from 1900 at the Paris World's Fair and was first patented in 1899 by Auguste Gaulin as an invention for "intimately mixing milk" using pressures up to $30 \mathrm{MPa}$ (French Patent no. 295.596) (2). Since then conventional homogenization extended the pressure range until $50 \mathrm{MPa}$. High pressure homogenization (HPH), also known as dynamic $\mathrm{HPH}$, has been repeatedly highlighted for its potential for pasteurization of food matrices at reduced thermal loads (3-6). HPH enables pressures 10-15 times higher than traditional homogenizers and covers the range 100-400 MPa within which the upper pressure range from 300 to $400 \mathrm{MPa}$ has been referred to as ultra high pressure homogenization (UHPH) (7). In this review, the range 100-200 MPa will be referred to as $\mathrm{HPH}$ and the range $>200 \mathrm{MPa}$ as UHPH. Inactivation of vegetative microorganisms has been demonstrated (3) and is achieved through a combined action of cavitation, shear stress, turbulence, impingement, and high pressure leading to disruption of the vegetative microorganism (8). It was shown that the efficiency of UHPH for vegetative microorganisms inactivation increased with the pressure level, the number of passes, the inlet, and valve temperatures but the exact mechanisms and interaction between parameters remain, however, to be elucidated (7). The valve temperature $\left(T_{\text {valve }}\right)$ showed a variable contribution to inactivation. While for $T_{\text {valve }}<60^{\circ} \mathrm{C}$, the mechanism of inactivation suggested a synergetic action of all stress factors, $T_{\text {valve }}>80^{\circ} \mathrm{C}$ seemed to lead to a temperature driven inactivation (7).
The progression toward UHPH has also opened the door to new sterilization opportunities, which might go past the initial theory that it might not be possible to inactivate spores by HPH (3). Bacterial spores, whose resistance to lethal treatments intensify the concern of their threat to food microbial safety (9), and their behavior when processed through UHPH are of prime interest. Comparatively, promising results could be achieved using high isostatic pressure thermal sterilization in model systems or products such as baby food $(10,11)$. Synergetic effects of temperature and isostatic pressure were demonstrated enabling a reduction of the total thermal load. However, this process is, to date, not available at industrial scale, and remains a batch process, which leads to significantly higher production costs than conventional thermal processes. Moreover, the minimum pressure required to achieve spore inactivation at high temperature is significantly higher than the UHPH pressure range $(>500 \mathrm{MPa})(10,11)$. The existing literature focusing on bacterial spore inactivation by UHPH is more recent and still faces inhomogeneity in conclusions. A recent extensive review of the technological aspects and potential applications of UHPH is available for the reader but only succinctly touched upon the topic of inactivation of bacterial spores by UHPH (7). In this short review, the existing literature focusing on bacterial spore inactivation by HPH and UHPH in different matrices, as well as the main learnings reached in terms of sterilization potential, is reviewed. A particular attention is given to the individual process parameters and target organisms in correlation with the achieved inactivation.

\section{BACTERIAL SPORE INACTIVATION BY HPH/UHPH IN MODEL SYSTEMS AND FOOD MATRICES}

Detailed work has been reported on the impact of high pressure on bacterial spores $(10,12,13)$. It could be shown that high pressure 
$(>600 \mathrm{MPa})$ and temperature $\left(>60^{\circ} \mathrm{C}\right.$ ) have a synergistic impact on bacterial spore inactivation (14). High pressure germination of bacterial spores was also achieved in the range $150-300 \mathrm{MPa} / 30$ $55^{\circ} \mathrm{C}(15,16)$, corresponding to ranges achieved by HPH/UHPH. Yet, it was shown that very short exposure to high pressure might not be sufficient to trigger germination if immediately followed by atmospheric pressure as was shown for Bacillus subtilis spores treated at $150 \mathrm{MPa} / 37^{\circ} \mathrm{C}$ for a few seconds (17). Furthermore, several investigations reported with $\mathrm{HPH} / \mathrm{UHPH}$ and spores failed at showing significant inactivation potential (4). However, a more in depth analysis of the work conducted this far on bacterial spore inactivation by HPH/UHPH shows that, often, a suboptimal process window might be responsible for this result.

The first study on the impact of HPH on bacterial spores was reported by Feijoo et al. (18). While the inlet and outlet temperatures were given, the actual maximal temperature of processing was not stated. A maximum spore reduction of $68 \%$ - that is 0.55 $\log _{10}$ - was reported for $200 \mathrm{MPa}$ and $50^{\circ} \mathrm{C}$ inlet temperature and though not successful in full spore inactivation, this work opened a new field of investigation.

Several following investigations within the $\mathrm{HPH}$ or $\mathrm{UHPH}$ domain also reported failure to strongly inactivate bacterial spores of different genera, species, and strains in model systems or food matrices (19-24) (Table 1). A common point to all these investigations is that the maximum valve temperature achieved was not stated, and/or relatively low, when one considers the applied inlet temperatures and estimates the valve temperature on the basis of $\sim 20^{\circ} \mathrm{C}$ increase per $100 \mathrm{MPa}$ (3). While some authors attributed spore resistance to a lower exposure area of proteins in the spore, as well as inner structure cross protection by Dipicolinic acid (DPA) (19), one might rather suspect that the thermal load necessary to achieve spore inactivation was not achieved and/or that the contribution of the other stress factors was insufficient to trigger sufficient inactivation.

Some authors attempted to combine HPH or UHPH with additional hurdles such as low $\mathrm{pH}(19,21)$, dimethyl dicarbonate $250 \mathrm{ppm}$ (24), or sodium benzoate (23). While Bevilacqua et al. (23) suggested that an interaction between HPH and sodium benzoate $(80 \mathrm{mg} / \mathrm{L})$ could occur in some cases (e.g., apple juice) for a specific strain of Alicyclobacillus acidoterrestris at low inoculums, this could not be generalized and all in all, it appears that none of these treatments were sufficient to achieve a cumulative or synergetic response in the spore inactivation by HPH or UHPH.

In the work of Chaves-López et al. (21), inactivation improved through multiple cycles and three cycles led to $5 \log _{10}$ reduction of Bacillus cereus spores (SV3, SV98, SV50, and SV108) and a corresponding DPA release of up to $52 \%$. This led the authors to suggest that the ultra-rapid depression during $\mathrm{HPH}$ treatments might cause a mechanical disruption of the coat and cortex, allowing DPA to leak out. However, it is reasonable to wonder why, with over $99.99 \%$ of spores inactivated, the DPA release did not reach $100 \%$. This difference in result suggests that other mechanisms

Table 1 | Overview of literature on non-successful HPH/UHPH inactivation of bacterial spores

\begin{tabular}{|c|c|c|c|c|c|c|c|c|}
\hline Equipment & Matrix & Spore strain & $\begin{array}{l}\text { Initial count } \\
\text { (spore/mL) }\end{array}$ & $\begin{array}{l}\text { Maximal reduction } \\
{\left[\log _{10}\left(\mathrm{~N} / \mathrm{N}_{0}\right)\right]}\end{array}$ & $\begin{array}{l}\text { Pressure } \\
\text { (MPa) }\end{array}$ & $T_{\text {inlet }}\left({ }^{\circ} \mathrm{C}\right)$ & $\begin{array}{l}\text { Max } \\
T_{\text {valve }}\left({ }^{\circ} \mathrm{C}\right)\end{array}$ & Source \\
\hline Microfluidizer® & Ice cream & $\begin{array}{l}\text { B. licheniformis ATCC } \\
14580\end{array}$ & $2.00 E+04$ & 0.55 & 200 & 50 & $?$ & $(18)$ \\
\hline $\begin{array}{l}\text { Niro Soavi } \\
\text { homogenizer }\end{array}$ & $\begin{array}{l}\text { Double } \\
\text { distilled water }\end{array}$ & $\begin{array}{l}\text { B. cereus SV3, SV98, } \\
\text { B. subtilis SV50, } \\
\text { SV108 }\end{array}$ & $\begin{array}{l}1.00 E+07- \\
1.00 E+08\end{array}$ & $\begin{array}{l}<0.5 \text { with single } \\
\text { pass - five with } \\
\text { three cycles }\end{array}$ & 150 & 20 & $?$ & $(21)$ \\
\hline $\begin{array}{l}\text { Panda - Niro } \\
\text { Soavi }\end{array}$ & $\begin{array}{l}\text { Laboratory } \\
\text { medium at } \mathrm{pH} \\
4.5 \text { and } 3.5\end{array}$ & $\begin{array}{l}\text { A. acidoterrestris } \\
\text { DSMZ 2498, Г4, and } \\
\text { c8 }\end{array}$ & $1.00 E+05$ & 0.67 (140-170 MPa) & $140-170$ & $?$ & $?$ & (19) \\
\hline $\begin{array}{l}\text { Panda - Niro } \\
\text { Soavi }\end{array}$ & $\begin{array}{l}\text { Malt extract } \\
\text { broth (pH 4.5) } \\
\text { and apple juice } \\
\text { (pH 3.7) }\end{array}$ & $\begin{array}{l}\text { A. acidoterrestris } \\
\text { DSMZ } 2498 \text { and } \Gamma 4\end{array}$ & $1.00 E+05$ & $0.82 \pm 0.07$ & 140 & $?$ & $?$ & (23) \\
\hline SFP FPG 12500 & Broth pH 4 & $\begin{array}{l}\text { A. acidoterrestris } \\
\text { N-1100, N-1108, } \\
\text { N-1096, SAC, OS-CAJ }\end{array}$ & $1.00 E+06$ & $<0.5$ & $100,200,300$ & $?$ & $?$ & $(24)$ \\
\hline $\begin{array}{l}\text { SFP FPG } \\
7400 \mathrm{H}: 350\end{array}$ & Skim milk & $\begin{array}{l}\text { G. stearothermophilus } \\
\text { ATCC 7953, } \\
\text { Clostridium } \\
\text { sporogenes PA } 3679\end{array}$ & $1.00 E+05$ & $\begin{array}{l}0.67(16 \\
\text { passes - } 300 \mathrm{MPa})\end{array}$ & $100-300$ & 45 & 84 & (22) \\
\hline SFP FPG 11300 & Milk 3.5\% fat & $\begin{array}{l}\text { Naturally present } \\
\text { spores }\end{array}$ & $5.00 E+01$ & 1.1 (200-300 MPa) & $100,200,300$ & 30,40 & 103 & $(20)$ \\
\hline
\end{tabular}


might be involved, leading to spore incapacity to grow post multiple cycles of HPH. Moreover, the mention that during multiple cycles, samples were successively treated without any storage suggests that the new inlet temperature might have been close to the first outlet temperature estimated at $45^{\circ} \mathrm{C}$ and likely even higher for the third cycle. No mention is made of the valve temperature and it is hard to estimate what might have been the most drastic conditions applied to the spores. An increasing processing valve temperature could be one possible explanation in the increasing inactivation observed. This hypothesis would also support why later work on thermo-resistant spores of Geobacillus stearothermophilus ATCC 7953 did not show any inactivation with up to 16 passes at $300 \mathrm{MPa}$ and a maximum valve temperature of $84^{\circ} \mathrm{C}(22)$. The interest of the work done by Pinho et al. (22) lies in the choice of strains and inoculation level, G. stearothermophilus ATCC 7953 and Clostridium sporogenes PA 3679 both at $10^{5}$ spore/mL, the former being the reference strain for wet heat sterilization and thus highly relevant when looking at UHPH sterilization. The study conducted at pressures between 100 and $300 \mathrm{MPa}$, however, concluded on an absence of inactivation of spores of both strains based on an inlet temperature of $45^{\circ} \mathrm{C}$ and maximum valve temperature of $84^{\circ} \mathrm{C}$. Furthermore, treatment did not change the $D$ and $z$-values of $G$. stearothermophilus and C. sporogenes, indicating that UHPH treatment at $300 \mathrm{MPa}$ did not sensitize the spores to thermal treatments nor cause germination. These results contradicted the results of Chaves-López et al. (21) and seem more likely considering the very short exposition time to high pressure $(<1 \mathrm{~s})$. The authors did not investigate higher inlet temperatures and therefore, did not reach higher temperature at the valve either. The conclusion on the absence of sterilization potential of UHPH might, here again, be linked to treatments done at too low valve temperatures to lead to inactivation.

Yet, multiple successful attempts at bacterial spore inactivation by HPH/UHPH were also reported (Table 2) (25-33). Most of this recent work was conducted in animal and vegetal milks and with higher pressures and inlet temperature ranges. Although the reported holding time at high temperature varies between studies, it could overall be approximated to $<1 \mathrm{~s}$. In spite of this very short time, one must consider the corresponding valve temperature (Table 2). For all studies where a full and durable inactivation of the native or inoculated spore flora could be achieved, the maximum temperature achieved (directly after the valve) was above $130^{\circ} \mathrm{C}$ and the pressure at $300 \mathrm{MPa}$. These recent studies are to date the best examples that UHPH is a promising technology to achieve commercial sterility of pumpable foods at the condition of using sufficiently high homogenization pressures and high inlet temperatures. A patent was published on January 26, 2012, which focuses on the use of UHPH for simultaneous sterilization and homogenization of pumpable foods and using the case of soy milk (34). The results in this patent correspond to the ones obtained in the studies introduced here above and confirm the potential of UHPH to inactivate endogenous spore formers. It nonetheless remains that the role of various stress factors during UHPH has not been investigated and the inactivation mechanisms remain to be established. While Valencia-Flores et al. (30) claims that the thermal treatment in combination with physical forces led to inactivation of endogenous vegetative cells and spores, no formal proof is given. The resulting high valve temperature seems to be a pre-requisite to any successful UHPH inactivation of mesophilic spore strains whose thermal resistance is limited. Using the indicated residence time at high temperature as well as the $D$ - and $z$-values of isolated strains within the product, it would have been interesting to estimate how much inactivation could be associated to the thermal load only. Additionally, assessing the full inactivation potential via inoculated samples would also have been interesting and was not conducted in the work of Valencia-Flores et al. (30). Also little work was conducted with highly thermoresistant bacterial strains (22). While the non-inoculated samples sterility could be assessed by shelf-life studies, the absence of high thermostable strains suggests a potential hazard in the process validation. Very recent work by Amador-Espejo et al. (31) initiated exploration of UHPH thermophilic spore inactivation with inoculation of whole UHT milk and showed that with an inlet temperature of $85^{\circ} \mathrm{C}, \mathrm{G}$. stearothermophilus spores could be inactivated. However, the strain used in this work was not ATCC 7953, the official wet heat sterilization indicator. If UHPH proves to be a thermally driven process, G. stearothermophilus ATCC 7953 would be recommended as indicator due its high resistance to wet heat inactivation (35).

\section{CONCLUSION}

Extensive work has been conducted on the impact of high isostatic pressure on bacterial spores and it has been shown that high pressure and temperature have a synergetic impact on bacterial spore inactivation. Significant germination of bacterial spores could also be achieved in the range 150-300 MPa, which would correspond to the range achieved by HPH. However, very short exposure to high isostatic pressure did not permit to trigger germination if immediately followed by atmospheric pressure as is for instance the case in $\mathrm{HPH} / \mathrm{UHPH}$ processing. This might explain the absence of significant germination by HPH/UHPH reported by some authors because the spores are exposed to high pressure for less than a second. The occurrence of spore germination could be interesting to allow for an easier inactivation by reducing the spore resistance to further thermal hurdles (for instance, a second UHPH cycle or the addition of a holding section at pasteurization temperature post UHPH) and future work will need to validate the (absence of) impact of HPH/UHPH on spore germination.

Most of the work which has been conducted on the investigation of $\mathrm{HPH} / \mathrm{UHPH}$ impact on bacterial spore inactivation is recent but has managed to raise significant hope and interest in this technology for continuous sterilization of pumpable foods. In light of the results gathered in this short review, the best inactivation could be achieved by combining the highest pressures $(\geq 300 \mathrm{MPa})$ and high inlet and valve temperatures for short holding time (less than $1 \mathrm{~s}$ ). One might expect a beneficial effect of UHPH on inactivation of bacterial spores through synergetic effect of pressure, shear, cavitation, temperature, and turbulence but this synergy remains to be established. Although the importance of temperature has been made clear (31), no studies found thus far were able to validly establish the effect of the other stresses such as cavitation or shear in the inactivation. Moreover, an estimation of the expected thermal inactivation through the thermal inactivation kinetic modeling of the strains considered and the residence 
Table 2 | Overview of literature on successful HPH/UHPH inactivation of bacterial spores.

\begin{tabular}{|c|c|c|c|c|c|c|c|c|}
\hline Equipment & Matrix & Spore strain & $\begin{array}{l}\text { Initial count } \\
\text { (spore/mL) }\end{array}$ & $\begin{array}{l}\text { Maximal reduction } \\
{\left[\log _{10}\left(\mathrm{~N} / \mathrm{N}_{0}\right)\right]}\end{array}$ & $\begin{array}{l}\text { Pressure } \\
\text { (MPa) }\end{array}$ & $T_{\text {inlet }}\left({ }^{\circ} \mathrm{C}\right)$ & $\begin{array}{l}\text { Max } \\
T_{\text {valve }}\left({ }^{\circ} \mathrm{C}\right)\end{array}$ & Source \\
\hline $\begin{array}{l}\text { SFP benchtop } \\
\text { homogenizer } \\
\text { nG12500 }\end{array}$ & $\begin{array}{l}\text { UHT whole } \\
\text { milk }\end{array}$ & $\begin{array}{l}\text { B. cereus (CECT 5144), } \\
\text { B. licheniformis } \\
\text { (DSMZ 13), } \\
\text { B. sporothermodurans } \\
\text { (DSMZ 10599), } \\
\text { B. coagulans (DSMZ } \\
\text { 2356), } \\
\text { G. stearothermophilus } \\
\text { (CECT 47), B. subtilis } \\
\text { (CECT 4002) }\end{array}$ & $\sim 1.00 \mathrm{E}+06$ & $\begin{array}{l}>5 \text { (for all strains at } \\
300 \mathrm{MPa} / 85^{\circ} \mathrm{C} \text { ) }\end{array}$ & 300 & $\begin{array}{l}55,65 \\
75,85\end{array}$ & $139.0 \pm 1.3$ & (31) \\
\hline SFP FPG 11300 & Soy milk & $\begin{array}{l}\text { Naturally present } \\
\text { spores }\end{array}$ & $2.34 \mathrm{E}+02$ & $2.13(300 \mathrm{MPa})$ & 200,300 & 40 & 108 & $(25,26)$ \\
\hline SFP FPG 11300 & $\begin{array}{l}\text { Almond } \\
\text { milk - soy milk }\end{array}$ & $\begin{array}{l}\text { Naturally present } \\
\text { spores }\end{array}$ & $\begin{array}{l}1.51 E+03 \\
(S)- \\
1.62 E+04(A)\end{array}$ & $\begin{array}{l}\mathrm{ND}\left(200 \mathrm{MPa} / 75^{\circ} \mathrm{C}-\right. \\
\left.300 \mathrm{MPa} / 65-75^{\circ} \mathrm{C}\right)\end{array}$ & 200,300 & $55,65,75$ & $135.7 \pm 1.5$ & (27) \\
\hline SFP FPG 11300 & $\begin{array}{l}\text { Almond } \\
\text { beverage - soy } \\
\text { milk }\end{array}$ & $\begin{array}{l}\text { Paenibacillus } \\
\text { taichungensis, } \\
\text { B. cereus, B. subtilis, } \\
\text { Lysinibacillus spp. }\end{array}$ & $\begin{array}{l}1.00 E+05- \\
1.00 E+06\end{array}$ & $\begin{array}{l}\text { ND for all except } \\
\text { B. cereus: } \sim 5\end{array}$ & 300 & $\begin{array}{l}55,65 \\
75,85\end{array}$ & $138.0 \pm 1.4$ & (28) \\
\hline SFP FPG 11300 & Soy milk & $\begin{array}{l}\text { Naturally present } \\
\text { spores (mesophilic and } \\
\text { B. cereus) }\end{array}$ & $\begin{array}{l}2.88 \mathrm{E}+03- \\
3.55 \mathrm{E}+03 \\
(\text { B. cereus })\end{array}$ & $\begin{array}{l}\text { ND after } \\
30^{\circ} \mathrm{C} / 20 \text { days } \\
\left(300 \mathrm{MPa} / 75^{\circ} \mathrm{C}\right)\end{array}$ & 200,300 & $55,65,75$ & $135.7 \pm 1.5$ & (29) \\
\hline
\end{tabular}

ND: not detected.

time could not be found. This could be a simple, yet interesting approach to validate the role of temperature versus other factors.

Additionally, this review underlines the absence of a clear surrogate to validate sterilization by UHPH. Many studies in food matrices looked at $B$. cereus spores and concluded on sterilization with full inactivation of this endogen pathogenic strain in the matrix. However, if the temperature is the main factor influencing inactivation, then validations ought to be conducted with thermostable strains such as the wet heat sterilization indicator G. stearothermophilus ATCC 7953 spores. Future studies with this indicator and higher inlet and valve temperature could be useful to validate the UHPH sterilization over a broader range of resistant spore formers.

One further key interest of this technology could lie in the fusion of two energy consuming steps, namely sterilization and homogenization, in one unit operation for classically homogenized fluids such as milks, thus reducing overall processing complexity and costs. For this, however, the physico-chemical and nutritional properties of the finished products will also need to be considered. Some of the studies considered in this review looked at the quality parameters of vegetal milks after UHPH and could show benefit from UHPH at $300 \mathrm{MPa}$ on the color and colloidal stability of soy milks by comparison to UHT $(25,29,33)$. It was also found that less furan were produced by UHPH at $300 \mathrm{MPa}$ than by UHT processing (28).

Finally, all the trials listed in this review were conducted using pilot scale equipment and scalability of the UHPH equipment to industrial level is not yet given. GEA Niro Soavi seems, to date, to be close to achieving this goal with the UHP4000 prototype with an aseptic design allowing for SIP and CIP cleanability on the process 
side and on the aseptic containment system for sterile product processes. This system operates from 100 up to $500 \mathrm{~L} / \mathrm{h}(36,37)$. BEE international commercializes homogenizers performing at $310 \mathrm{MPa}$ up to $1500 \mathrm{~L} / \mathrm{h}$ (38), while the spin-off Ypsicon, founded in 2013, advertises an equipment with aseptic filling applying $350 \mathrm{MPa}$ and $1000 \mathrm{~L} / \mathrm{h}$ (39). However, to date, no example of the use of these two pieces of equipment for commercial products by industry was found.

In conclusion, the state of the art given in this review suggests that UHPH has indeed strong potential as an emerging technology for sterilization of pumpable foods in combination with classical homogenization; however, further research work is required for reliable validation of this promising technology.

\section{ACKNOWLEDGMENTS}

The authors gratefully acknowledge the Nestlé Research Center, Lausanne for its financial support.

\section{REFERENCES}

1. Donsí F, Ferrari G, Maresca P. High-pressure homogenization for food sanitization. In: Barbosa-Canovas GV, Mortimer A, Lineback D, Spiess W, Buckle $\mathrm{K}$, Colonna P, editors. Global Issues in Food Science and Technology. London: Elsevier Science (2009). p. 309-52.

2. Gaulin A. System for Intimately Mixing Milk. USA Patent Application 125440 (1899).

3. Popper L, Knorr D. Application of high-pressure homogenisation for food preservation. Food Technol (1990) 84:84-9.

4. Diels AM, Michiels CW. High-pressure homogenization as a non-thermal technique for the inactivation of microorganisms. Crit Rev Microbiol (2006) 32:201-16. doi:10.1080/10408410601023516

5. Belloch C, Gurrea MC, Tárrega A, Sampedro F, Carbonell JV. Inactivation of microorganisms in orange juice by high-pressure homogenization combined with its inherent heating effect. Eur Food Res Technol (2012) 234:753-60. doi:10.1007/s00217-012-1698-7

6. Poliseli-Scopel FH, Hernández-Herrero M, Guamis B, Ferragut V. Characteristics of soymilk pasteurized by ultra high pressure homogenization (UHPH). Innov Food Sci Emerg Technol (2013) 20:73-80. doi:10.1016/j.ifset.2013.06.001

7. Dumay E, Chevalier-Lucia D, Picart-Palmade L, Benzaria A, Gràcia-Julià A, Blayo C. Technological aspects and potential applications of (ultra) high-pressure homogenisation. Trends Food Sci Technol (2013) 31:13-26. doi:10.1016/j.tifs. 2012.03.005

8. Kleinig AR, Middelberg APJ. On the mechanism of microbial cell disruption in high-pressure homogenisation. Chem Eng Sci (1998) 53:891-8. doi:10.1016/j. watres.2010.07.030

9. Georget E, Reineke K, Heinz V, Knorr D, Ananta E, Mathys A. Spore inactivation mechanisms during industrial food and equipment sterilization. In: Heldman DR, Wheeler MB, Hoover DG, editors. Encyclopedia of Biotechnology in Agriculture and Food. New York: Taylor \& Francis (2013). p. 1-6.

10. Mathys A. Inactivation Mechanisms of Geobacillus and Bacillus Spores during High Pressure Thermal Sterilization. Ph.D. thesis. Berlin: Technische Universität Berlin (2008).

11. Sevenich R, Kleinstueck E, Crews C, Anderson W, Pye C, Riddellova K, et al. High-pressure thermal sterilization: food safety and food quality of baby food puree. J Food Sci (2014) 79:230-7. doi:10.1111/1750-3841.12345

12. Reineke K. Mechanisms of Bacillus Spore Germination and Inactivation during High Pressure Processing. Dr. Ing. Ph.D. thesis. Berlin: Technischen Universität Berlin (2012).

13. Reineke K, Mathys A, Heinz V, Knorr D. Mechanisms of endospore inactivation under high pressure. Trends Microbiol (2013) 21:296-304. doi:10.1016/j. tim.2013.03.001

14. Mathys A, Reineke K, Heinz V, Knorr D. High pressure thermal sterilizationDevelopment and application of temperature controlled spore inactivation studies. High Pres Res (2009) 29:3-7. doi:10.1080/08957950802526469

15. Reineke K, Doehner I, Schlumbach K, Baier D, Mathys A, Knorr D. The different pathways of spore germination and inactivation in dependence of pressure and temperature. Innov Food Sci Emerg Technol (2012) 13:31-41. doi:10.1016/j.ifset.2011.09.006

16. Georget E, Kapoor S, Winter R, Reineke K, Song Y, Callanan M, et al. In situ investigation of Geobacillus stearothermophilus spore germination and inactivation mechanisms under moderate high pressure. Food Microbiol (2014) 41:8-18. doi:10.1016/j.fm.2014.01.007

17. Kong L, Doona CJ, Setlow P, Li Y-Q. Monitoring rates and heterogeneity of high pressure germination of Bacillus spores using phase contrast microscopy of individual spores. Appl Environ Microbiol (2013) 80:345-53. doi:10.1128/AEM. 03043-13

18. Feijoo SC, Hayes WW, Watson CE, Martin JH. Effects of microfluidizer technology on Bacillus licheniformis spores in ice cream mix. J Dairy Sci (1997) 80:2184-7. doi:10.3168/jds.S0022-0302(97)76166-6

19. Bevilacqua A, Cibelli F, Corbo MR, Sinigaglia M. Effects of high-pressure homogenization on the survival of Alicyclobacillus acidoterrestris in a laboratory medium. Lett Appl Microbiol (2007) 45:382-6. doi:10.1111/j.1472-765X. 2007.02219.x

20. Pereda J, Ferragut V, Quevedo JM, Guamis B, Trujillo AJ. Effects of ultra-high pressure homogenization on microbial and physicochemical shelf life of milk. $J$ Dairy Sci (2007) 90:1081-93. doi:10.3168/jds.S0022-0302(07)71595-3

21. Chaves-López C, Lanciotti R, Serio A, Paparella A, Guerzoni E, Suzzi G. Effect of high pressure homogenization applied individually or in combination with other mild physical or chemical stresses on Bacillus cereus and Bacillus subtilis spore viability. Food Control (2009) 20:691-5. doi:10.1016/j.foodcont.2008.09. 001

22. Pinho CRG, Franchi MA, Tribst AAL, Cristianinia M. Effect of high pressure homogenization process on Bacillus stearothermophilus and Clostridium sporogenes spores in skim milk. Procedia Food Sci (2011) 1:869-73. doi:10.1016/j. profoo.2011.09.131

23. Bevilacqua A, Corbo MR, Sinigaglia M. High-pressure homogenisation and benzoate to control Alicyclobacillus acidoterrestris: a possible way? Int J Food Sci Technol (2012) 47:879-83. doi:10.1111/j.1365-2621.2011.02913.x

24. Chen W, Harte FM, Davidson PM, Golden DA. Inactivation of Alicyclobacillus acidoterrestris using high pressure homogenization and dimethyl dicarbonate. $J$ Food Prot (2013) 76:1041-5. doi:10.4315/0362-028X.JFP-12-443

25. Cruz N, Capellas M, Hernandez M, Trujillo AJ, Guamis B, Ferragut V. Ultra high pressure homogenization of soymilk: microbiological, physicochemical and microstructural characteristics. Food Res Int (2007) 40:725-32. doi:10.1016/ j.foodres.2007.01.003

26. Cruz N. Effecto de la Ultra Alta Presión de Homogeneización en Licuado de Soja y su Comportamiento en el Desarrollo de un Producto Fermentado. Ph.D. thesis. Barcelona: Universitat Autònoma de Barcelona (2008).

27. Ferragut V, Hernández-Herrero M, Poliseli F, Valencia D, Guamis B. Ultra high pressure homogenization (UHPH) treatment of vegetable milks: improving hygienic and colloidal stability. In: Yanniotis S, Taoukis P, Stoforos NG, Karathanos VT, editors. Proceedings of the 11th International Congress on Engineering and Food (ICEF11) - Food Process Engineering in a Changing World, Vol. II. Athens: Cosmosware (2011). p. 1193-4.

28. Poliseli-Scopel FH. Study of the Ultra High Pressure Homogenization (UHPH) Technology for Producing High Quality Soymilk. Ph.D. thesis. Barcelona: Universitat Autònoma de Barcelona (2012).

29. Poliseli-Scopel FH, Hernández-Herrero M, Guamis B, Ferragut V. Comparison of ultra high pressure homogenization and conventional thermal treatments on the microbiological, physical and chemical quality of soymilk. Food Sci Technol (2012) 46:42-8. doi:10.1111/1750-3841.12029

30. Valencia-Flores DC, Hernandez-Herrero M, Guamis B, Ferragut V. Comparing the effects of ultra-high-pressure homogenization and conventional thermal treatments on the microbiological, physical, and chemical quality of almond beverages. J Food Sci (2013) 78:199-205. doi:10.1111/1750-3841.12029

31. Amador-Espejo GG, Hernández-Herrero MM, Juan B, Trujillo AJ. Inactivation of Bacillus spores inoculated in milk by ultra high pressure homogenization. Food Microbiol (2014) 44:204-10. doi:10.1016/j.fm.2014.06.010

32. Amador-Espejo GG, Suàrez-Berencia A, Juan B, Bárcenas ME, Trujillo AJ. Effect of moderate inlet temperatures in ultra-high-pressure homogenization treatments on physicochemical and sensory characteristics of milk. J Dairy Sci (2014) 97:659-71. doi:10.3168/jds.2013-7245

33. Poliseli-Scopel FH, Hernández-Herrero M, Guamis B, Ferragut V. Sterilization and aseptic packaging of soymilk treated by ultra high pressure homogenization. Innov Food Sci Emerg Technol (2014) 22:81-8. doi:10.1016/j.ifset.2014.01.001 
34. Guamis B, Trujillo AJ, Ferragut V, Quevedo JM, López T, Buffa MN. Continuous System and Procedure of Sterilization and Physical Stabilization of Pumpable Fluids by Means of Ultra-High Pressure Homogenization. Spain Patent Application PCT/EP2011/003572 (2012).

35. Albert H, Davies DJG, Woodson LP, Soper CJ. Biological indicators for steam sterilization: characterization of a rapid biological indicator utilizing Bacillus stearothermophilus spore-associated alpha-glucosidase enzyme. J Appl Microbiol (1998) 85:865-74. doi:10.1046/j.1365-2672.1998.00607.x

36. Gandini M, Grandi S. A Homogeniser for the Continuous Treatment of Fluids at Very High Pressure. Italy Patent Application 04769899.8 (2007).

37. Grasselli S, Gandini M, Grandi S. Method and Apparatus for Disrupting Cells in a Fluid Suspension by Means of a Continuous Process. USA Patent Application 10/937338 (2007).

38. BEE International. DeBEE Production System [Online]. (2014). Available: http:// cdn2.hubspot.net/hub/231301/file-20766078-pdf/docs/debee_production.pdf

39. Ypsicon. UHPH: The Future of Beverage Sterilization [Online]. (2014). Available from: http://ypsicon.com/welcome.html
Conflict of Interest Statement: The authors declare that the research was conducted in the absence of any commercial or financial relationships that could be construed as a potential conflict of interest.

Received: 05 June 2014; paper pending published: 16 July 2014; accepted: 01 August 2014; published online: 19 August 2014.

Citation: Georget E, Miller B, Callanan M, Heinz V and Mathys A (2014) (Ultra) high pressure homogenization for continuous high pressure sterilization of pumpable foods - a review. Front. Nutr. 1:15. doi: 10.3389/fnut.2014.00015

This article was submitted to Nutrition and Food Science Technology, a section of the journal Frontiers in Nutrition.

Copyright (c) 2014 Georget, Miller, Callanan, Heinz and Mathys. This is an openaccess article distributed under the terms of the Creative Commons Attribution License (CC BY). The use, distribution or reproduction in other forums is permitted, provided the original author(s) or licensor are credited and that the original publication in this journal is cited, in accordance with accepted academic practice. No use, distribution or reproduction is permitted which does not comply with these terms. 